\title{
USING LESSON STUDY TO CONNECT PROCEDURAL KNOWLEDGE WITH MATHEMATICAL THINKING
}

\author{
Patsy Wang-Iverson, Gabriella and Paul Rosenbaum Foundation \\ Marian Palumbo, Bernards Township Public Schools
}

Developing U.S. students' mathematical thinking frequently is an elusive goal. The reasons are varied. Some of them include: 1. teachers' own lack of understanding of mathematics caused in part by an absence of a coherent mathematics curriculum (Schmidt et al., 2002) ; 2. insufficient or no professional development focused on the scope and sequence of mathematics within and across the grades; 3. inadequate knowledge and concrete examples of what mathematical thinking entails for both students and teachers; 4. lack of clear and explicit examples for how to connect students' procedural knowledge with conceptual understanding through mathematical thinking.

To focus APEC (Asia-Pacific Economic Cooperation) member economy specialists' attention on the importance of and approaches to the development of mathematical thinking of both students and teachers, the 2-7 December 2006 APEC lesson study conference in Tokyo/Sapporo, Japan, offered various keynote presentations (Katagiri, March, 2007, Lin, March, 2007, Stacey, March, 2007, Tall, March 2007). The speakers shared their perspectives on approaches to developing mathematical thinking, thus setting the stage for observation and discussion of four lessons, discussion of specialists' papers on mathematical thinking, and preparation for work following the conference. Prior to the end of the conference, the APEC member economy specialists were charged with the task of returning to their country and conducting a lesson study cycle that helped teachers work with their students to develop mathematical thinking skills while working on a specific mathematical concept.

\section{Getting Started}

To carry out the assigned task, the U.S. representative to the APEC lesson study conference (Wang-Iverson) invited the mathematics supervisor (Palumbo) at Bernards Township Public Schools (New Jersey) to identify a group of teachers willing to participate in lesson study. Although lesson study has been implemented at various sites across the United States since $1999^{1}$, the team of five grade seven teachers (William Annin Middle School) that agreed to participate in the project was new both to lesson study and to discussing collaboratively how to develop students' mathematical thinking. Palumbo had engaged in lesson study previously with a few high school mathematics teachers, but she had not established a systemic lesson study initiative. The project thus

\footnotetext{
${ }^{1}$ Paterson School No. 2 was the first U.S. school to begin lesson study, under the tutelage of teachers from Greenwich Japanese School, a relationship facilitated by Makoto Yoshida (2004).
} 
was two-pronged: introducing these individuals to the purpose, practice, and outcomes of lesson study and facilitating their collaborative work to develop student mathematical thinking through creating and teaching a lesson.

A unique feature of this district is that subject matter teachers at the same grade meet regularly to identify and discuss topics to be covered the following week and to share responsibilities for developing worksheets and homework assignments to be used across the classes. Although regular meetings are common in some districts, rarely do teachers progress at the same pace and share worksheets. What did not occur, prior to their engagement with lesson study, was observing each other's classes and discussing what was observed and what changes needed to be made to foster better student learning. These teachers' lack of opportunity to observe their peers and to be observed in turn is not an uncommon phenomenon across most countries, but U.S. teachers have even fewer opportunities. Internationally, 27\% of grade 8 students participating in TIMSS 2003 had teachers who reported they had opportunities to observe colleagues two to three times a month; in the U.S. the number was $11 \%$. Eighty-five percent of U.S. students had teachers reporting they have never observed or been observed by colleagues (Mullis et al. 2004).

During the introduction to lesson study, the teachers identified the characteristics of ideal students vs. the real students they encountered in their classes (see Appendix 1). This list was to serve as the basis for developing a lesson focused on moving students toward more idealistic behavior in learning mathematics. A common trait among students was their focus on simply getting the right answer and moving on to the next task.

Given the common schedule shared by the teachers, they next reviewed the topic they would be covering around the spring dates selected for teaching the lesson. However, after observing some classes on proportions and noting students' tenuous grasp of the concept, the authors suggested the teachers might wish to revisit the concepts of percent and proportion and create a lesson that helped strengthen students' understanding of those topics.

Facilitated by the mathematics supervisor, the teachers developed a lesson study schedule that allowed them to meet weekly or biweekly to plan and develop the lesson. The supervisor suggested the lesson study group use moodle (www.moodle.com), a webbased platform, to document conversations between meetings, which then could be archived. However, this practice was not maintained throughout the lesson study process, as it introduced yet another new undertaking for the teachers in the midst of continuing their regular work of daily teaching. 
After a very brief introduction to kyozaikenkyu ${ }^{2}$ (Takahashi et al., 2005), the teachers investigated various resources to find problems they wanted to use in their lesson. Through their individual exploration of resources beyond just the textbook, the teachers selected problems that might push student thinking about fractions, percents and proportions. They then reviewed the problems and ranked them. At a subsequent meeting they discussed the merits of the problems selected and agreed upon one problem, which is the first problem presented in the lesson plan (Appendix 2):

Problem: The Carters are buying a new iPod Nano. Three stores have on sale this week the model they want, but they have decided to shop at Ralph's, because they think Ralph's is offering a "double discount." Here are the ads. Did the Carters make a wise decision? Explain.

\begin{tabular}{|l|l|l|}
\hline $\begin{array}{l}\text { Radio Shop } \\
\text { Original Price } \$ 172 \\
\text { Discount: } 1 / 4 \text { off }\end{array}$ & $\begin{array}{l}\text { Discount City } \\
\text { Original Price: } \$ 180 \\
\text { Discount: } 30 \% \text { off }\end{array}$ & $\begin{array}{l}\text { Original Price } \$ 180 \\
\text { Discount: } 10 \% \text { off with an } \\
\text { additional } 20 \% \text { off the } \\
\text { discounted price }\end{array}$ \\
\hline
\end{tabular}

Identifying the goals was not a simple task; such an approach previously had not been the norm in preparing a lesson. The goals elucidated in the final lesson plan for the Algebra I lesson were focused more on the specific skills rather than on developing students' mathematical thinking:

a. Understand the value for using efficient methods when solving percent problems

b. Compare and contrast the relationship(s) between determining the "part" and "determining the "whole" in a percent problem

\section{Developing and teaching the lesson}

The lesson plan evolved over several meetings. One teacher volunteered to work on writing the rationale for choosing the particular lesson problem, another focused on writing the lesson plan itself, and the supervisor and one of the teachers who also taught grade six developed the scope and sequence of concepts taught in the earlier grades (see lesson plan in Appendix 2). However, in the effort to move on to develop the lesson plan,

\footnotetext{
2 "investigation of instructional materials," encompassing not just textbooks, teacher manuals, and mathematics manipulatives, but a wider range of materials, including the course of study (standards), the educational context, learning goals, tools, research and case study publications, lesson plans and reports from lesson study open houses, and ideas gained from research lesson observations. Kyozaikenkyu also includes investigation of students' prior knowledge, learning experiences, state of learning and understanding, which makes it possible for teachers to be able to anticipate students' reactions and solutions to the problems students study during the lesson.
} 
the scope and sequence and the accompanying text pages were not studied in detail and discussed by the group in planning the lesson.

Initially, the teachers seemed reluctant to volunteer to teach the lesson, but at the next meeting, they all expressed a desire to teach, as they were interested in having their colleagues observe their students. It was agreed that the lessons would go through two paired iterations in grade 7 classrooms followed by a final iteration in a grade 7 algebra classroom (see table). Two teachers would conduct the first teaching (1-1 and 2-1); to avoid being influenced by the first lesson, the second teacher would not observe the first lesson. This format did not follow the usual lesson study process, where one teacher volunteers to teach the lesson, followed by discussion and revision of the lesson. Whether teaching of the revised lesson takes place varies across lesson study groups.

The structure adopted for this lesson study project provided more opportunities for the teachers to practice their observational skills focused on student thinking and learning. Following the lessons, the team met to share and discuss the data collected and to revise the lesson for the second teaching by two more teachers.

During the first teaching the students simply had been asked to solve the problems on the worksheet. For the second teaching, students received a worksheet that provided room for them to solve the problem in more than one way and to record the time when they finished the problem (see Fig. 1). The time recorded by the students provided useful data for the teachers for scheduling more effectively in the future the amount of time needed by students to complete assigned tasks. The students in these two classes were asked to write down their reflections on a form containing specific questions (see Appendix 2). After the second teaching, the lesson was revised again and re-taught by the teachers in their other classes without observers.

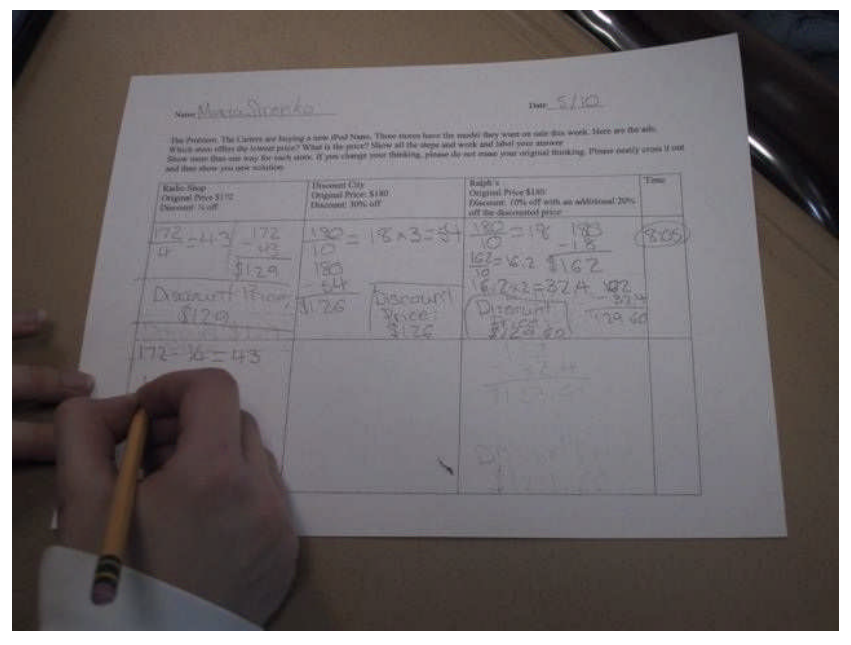

Figure 1. Student worksheet

Table: Teaching sequence for observed lessons 


\begin{tabular}{|l|l|l|l|}
\hline & First teaching & Second teaching & Third teaching \\
\hline Teacher \#1 & $1-1$ & & \\
\hline Teacher \#2 & $2-1$ & & \\
\hline Teacher \#3 & & 3-2 (with calculator) & \\
\hline Teacher \#4 & & 4-2 (w/o calculator) & \\
\hline Teacher \#5 & & & $5-3$ (algebra) \\
\hline
\end{tabular}

Investigating additional factors

Two teachers used the lesson to investigate how other factors affect student thinking:

1) Calculator usage: One of the teachers during the second teaching of the lesson did not give students calculators to use during the lesson, which provided an opportunity for observers to analyze differences in student work and thinking with/without the use of calculators.

2) Advanced students: One of the teachers who taught a grade 7 algebra class in addition to regular grade 7 mathematics classes further modified the lesson and taught it to the algebra class (final teaching of the lesson). She was able to assess the differences in mathematical thinking between the grade 7 regular mathematics students and her grade 7 algebra students, who were considered more advanced mathematically.

\section{Documentation of student work}

During the first teaching of the lesson, some students attempted to solve the problem using proportions but set up the problem incorrectly (see Fig. 2):

$25 / 172=x / 100 ; 30 / 180=x / 100 ; 10 / 180=x / 100$

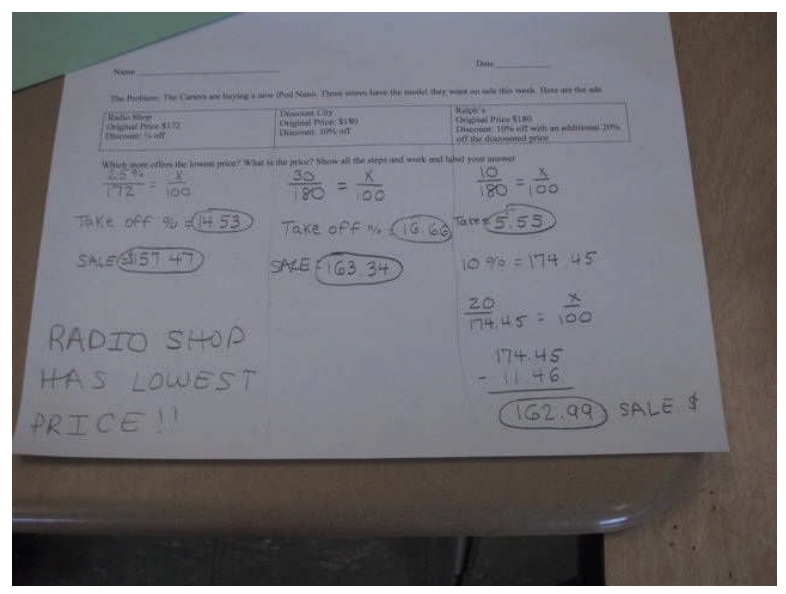

Figure 2: Error using proportions 
As a result, students were not in agreement on which discount provided the lowest price. For students who arrived at the correct conclusion that Discount City provided the largest discount, they first calculated the discount and then subtracted the value from the original price:

Given: $\$ 180=$ original price; $30 \%$ discount

$180 \times 0.3=54$

$180-54=\$ 126=$ discounted price at Discount City

No students in these two classes solved the problem by directly calculating the fraction or percent of the original price:

$180 \times 0.7=\$ 126=$ discounted price at Discount City

In the second iteration of the lesson, when students were asked to solve the problem in more than one way, seven out of 25 students in one class subtracted $1 / 4$ from one and found $3 / 4$ of $\$ 172$ to calculate the discount price at Radio Shop. In the other class, only one student used this method to solve the problem. Most of the other students, in trying to find a different method, moved between multiplying by a fraction and multiplying by the fraction's decimal representation, considering these to be different solution methods. Six of the 44 students in the two classes did not show a second way of solving the problem. These results implied the students may not have been used to being asked to solve problems by more than one method, and some did not understand what it meant to think about tackling the problems in different ways.

\section{Confronting a more challenging problem}

During the first teaching of the lesson (1-1 and 2-1), no student was able to solve the additional problem, which asked for the original price of the computer, given the discounted price:

Additional problem: A computer is discounted $20 \%$ from its original price because it didn't sell. The store took an additional 30\% off the discounted price. Barbara purchased the computer for $\$ 896$. What was the original price of the computer?

Three students in one of the classes during the second iteration of the lesson obtained the correct original price: one student had the correct calculator-generated answer but no written record, while the other two students solved the problem using the following steps:

$$
\begin{aligned}
& 100 \%-30 \%=70 \% \\
& 896 \div 70 / 100=896 \times 100 / 70=89600 / 70=1280 \\
& 100 \%-20 \%=80 \% \\
& 1280 \div 100 / 80=\$ 1600
\end{aligned}
$$


In using the above steps, these students were able to apply the knowledge used in the earlier problem (subtracting the discount from 100\%), but they needed to go one step further to realize that in order to calculate the original price, they needed to divide rather than multiply. Students who were not able to solve the problem correctly did make valiant efforts, trying to apply what they had learned previously. Some set up the proportion formula, $a / b=p / 100$ (taught earlier in the year by the teacher from the textbook), but then did not know what to do next, demonstrating they remembered but did not understand the formula (Stacey, 2007, p. 45). Students fell into the trap of either multiplying the discounted price by the percent discount $(\$ 896 \times 0.3$ ) or dividing by the percent discount $(\$ 896 \div 0.3)$. Other students multiplied by 0.8 and 0.7 . A few students knew to divide by $70 \%$ but then divided by 7 and not 0.7 . Further analysis and conversation with the students might have helped to determine whether this error is merely computational in nature or reveals a more fundamental problem in moving from percent to decimal notation.

One student arrived at an answer of $\$ 949.76$ by the following route:

$896 \times 0.3=268.8$

$268.8 \times 0.2=53.76$

$896+53.76=\$ 949.76$

The student incorrectly applied the strategy used in the earlier problem (Ralph's store): sequential multiplication. In this case, seeing that $\$ 53.76$ could not be correct, since the original price had to be greater than the discounted price, s/he then simply added this value to the final discounted price to arrive at the 'original' price. This solution illustrates the student's tenuous grasp of the earlier solution method, leading to an inability to apply it to a different problem.

Another student obtained an answer of \$1396.96 using the following method:

$896 \times 0.3=2684 / 5$

$896+2684 / 5$

$1164.8 \times 2 / 10=252.96$

$1164+232.96=\$ 1396.96=$ original price

In addition to moving between the use of fraction and decimal in solving the problem incorrectly, this student also tried to apply directly what was previously discussed for a different problem to find the discounted price. Perhaps in an effort to compensate for the difference between the two problems, in lieu of subtracting, the student added to arrive at the original price. In this case it would have been useful to ask the student to explain the thinking behind the calculations.

The above two examples illustrate students' readiness to 'push buttons' to arrive at an answer but an inability to evaluate the work to make sense of the calculations. In 
developing mathematical thinking, students need to learn to slow down and to be taught explicitly how to engage in metacognition, scrutinizing one's own thinking. This lesson study cycle revealed the need to help students move beyond simply applying algorithms without considering whether they make sense for solving the specific problems.

In the advanced class there were no computational errors. Twelve of the 16 students solved the iPod problem by first calculating the discount and then subtracting it from the original price; the remaining four students directly calculated the discounted price for the iPod problem. These same four students calculated the price at Ralph's using a two-step process: first calculating the $10 \%$ discount followed by the $20 \%$ discount.

One student in this advanced class initially calculated the answer for Ralph's by the following method:

$180 \times 0.1=18$

$180-18=162$

$162 \times 0.2=32.4$

$162-32.4=\$ 129.60$

From this solution, she then was able to reduce the steps to one equation:

$x=(180)(0.9)(0.8)($ see Fig. 3$)$.

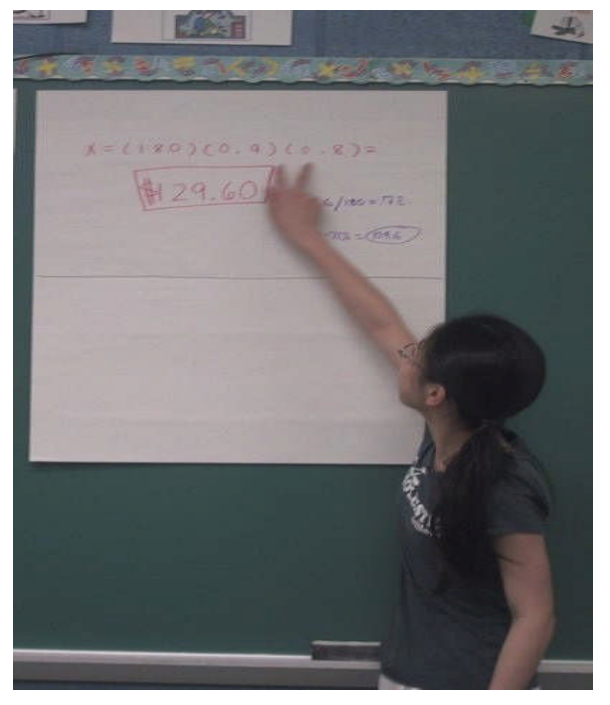

Figure 3: Expressing the iPod problem in one step.

After the student presentations, the teacher summarized the approach to using a one-step equation to finding the cost of the iPod at Ralph's. She then asked the students to solve the computer problem. The majority of students did not solve the problem correctly; in that time period they were not able to transfer what they had learned from the previous problem. A few students were able to solve the problem by first dividing by 0.7 and then 
dividing by 0.8 , which was a solution anticipated by the teacher (see lesson plan in Appendix 2). One student reduced the equation to:

Original price $=896 \div 0.56=\$ 1600$

For most of the students, using the more efficient method of solving for a double discount presented a new way of thinking about the problem. In hindsight, perhaps they needed to have first solved a problem asking for the original price after a single discount and then move on to the computer problem with its two discounts ${ }^{3}$.

\section{Student discourse}

Students worked in pairs in all the classes. Three patterns of behavior ${ }^{4}$ were observed: 1. although asked to work with a partner, students worked silently and individually; 2 . one student immediately took charge and told the other student what to do; 3 . the two students worked as a team, discussing their answers as they worked.

Two students in particular during the third teaching (5-3) carried out a prolonged discussion of their answer of $\$ 14,933.30$ for the computer problem, which they had obtained by dividing the sale price of $\$ 896$ by 0.3 and then by 0.2 . The original price they obtained seemed too high to them, but in checking it, using the same decimals, they came up with the same number. They concluded the answer had to be right, despite feeling perplexed by the large number. Neither student questioned the validity of their thinking; they simply checked their calculation without considering that perhaps they were using the wrong numbers.

Another pair of students in class 4-2 engaged in a debate over what one student had written for the proportion they had set up. The second student insisted the first student's work was wrong, while the first student replied that what she had written was correct. The first student finally understood the source of the second student's disagreement and said that the proportion she had set up was correct, but that she simply had written it as $p / 100=a / b$, rather than $a / b=p / 100$, which was the standard way shown by the teacher and the textbook. This exchange revealed that one student understood the formula (understood that the two sides of an equal sign can be exchanged without changing the

\footnotetext{
${ }^{3}$ Japanese lesson 3 from the TIMSS Video Study (www.rbs.org/international/timss/resource_guide/lessons/by_country.php\#japan) was an introduction to inequalities. After the teacher summarized the student solutions, he then presented a second, easier problem, which would allow all students to solve it using inequalities.

${ }^{4}$ From this behavior, it appeared some students did not understand the benefits of working with a partner (Gould, 2007), and there might not have been whole class discussion of the purpose of working collaboratively.
} 
relationship), while the other student simply remembered the formula (Stacey, 2007, p. 45).

According to Gould (March, 2007), "Learning to argue about mathematical ideas is fundamental to understanding mathematics." To be prepared to argue, students need to be able to listen to and respond to each other's explanation of their work and thinking. The above issue was resolved, because the first student was able to listen to and understand her partner's point of dissension.

\section{Mathematical thinking}

Although the term 'mathematical thinking' is used over 100 times in the Principles and Standards of School Mathematics (NCTM, 2000), no clear and explicit definition is provided. Stacey (March, 2007, pp. 39-40) described mathematical thinking as a "highly complex activity", a process “...best discussed through examples." Katagiri (March, 2007) also does not provide a clear definition, but he illustrates the logical steps (in order of complexity) of mathematical thinking for a counting problem that he used as an example (p. 115):

- Clarification of the meaning of the problem

- Coming up with a convenient counting method

- Sorting and counting

- Coming up with a method for simply and clearly expressing how the objects are sorted

- Encoding

- Replacing with easy-to-count things in a relationship of functional equivalence

- Expressing the counting methods as a formula

- Reading the formula

- Generalizing

Mathematical thinking is "the most important ability that arithmetic and mathematics courses need to cultivate in order to instill in students this ability to think and make judgments independently (p. 108)..."To be able to independently solve problems and expand upon problems and solving methods, the ability to use "mathematical thinking" is even more important than knowledge and skill, because it enables to drive the necessary knowledge and skill (p. 110). A working group composed of computer scientists and mathematicians offers a very general definition of mathematical thinking as "applying mathematical techniques, concepts and processes, either explicitly or implicitly, in the solution of problems." (Henderson et al., 2001).

The ability to think and make judgments independently has been the goal of Japanese education since 1950, but it still remains to be achieved (Katagiri, p. 108). Such is the case also in the United States. As U.S. teachers turn to lesson study in mathematics to 
help them develop the ability to better understand and analyze student thinking and learning, they are finding they first need to understand how the students are thinking (or not thinking) about the mathematics they are being taught and then learn to move students from simply following and applying procedures in very rigid and limited ways to developing the ability to determine for themselves which procedures to use, how to achieve a level of efficiency in solving the problems, and whether what they have done makes sense.

\section{Key window for considering mathematical thinking}

The key window in this lesson study was communication, at the levels of teacher-toteacher, teacher-to-student and student-to-student communications. In planning for the first teaching, there was no discussion of solution efficiency, and anticipation of student thinking and misunderstanding was limited. After observing the first teachings, the teachers discussed the need to probe more deeply students' understanding of the problem by offering counter-examples ${ }^{5}$ to student solutions to push their thinking. For the second teaching it was agreed that students would be asked to consider if a $10 \%$ discount followed by a $20 \%$ discount was the same as or different from a $20 \%$ discount followed by a $10 \%$ discount. The students would also be urged to support their answer mathematically. After the two iterations of teaching, the teachers also began to focus on the need to help students consider how to solve problems by looking for studentgenerated efficient solutions and discussing them as a whole class.

At the level of student-to-student communication, the teachers began orchestrating more carefully the sharing of the student solutions, encouraging the students to communicate their solution strategies in a sequential fashion in order to enhance student understanding. The student presentations were planned to flow from the concrete to the abstract, from specific to general, from "ordinary solutions" to "efficient solutions." This teaching strategy was learned from watching a TIMSS video of a Japanese teacher orchestrating the student solution process (Hiebert, et al., 2003) prior to beginning the lesson study cycle.

\section{What did teachers learn?}

Subsequent to this first experience with lesson study, the teachers now report that in planning lessons, they think more carefully about anticipating students' solutions and orchestrating the manner in which the students communicate the solutions to the other members of the class. This is a change from the process previously in place, in which the teachers randomly selected students to come to the board to explain a solution to the problem. When the teachers used this practice (random selection versus planned selection

\footnotetext{
${ }^{5}$ For calculating Ralph's discount, the teacher might ask why one couldn't first add $10 \%$ and $20 \%$ and then multiply the original price by $30 \%$.
} 
of student solutions), the flow of the lesson could be interrupted by "surprises" that could also confuse or misdirect students away from the learning objective.

Teachers reflected upon this first lesson study experience by responding to a series of questions (see Appendix 4). One of the main impacts of the lesson study cycle was to strengthen the teachers' ability to examine students working in the classroom and to discuss their observations, in turn making the teachers themselves more reflective thinkers, as documented in their questionnaire responses. Through the eyes of their colleagues, they learned more about their students' thinking; they obtained information about students beyond what was written on the student worksheets. Questions posed by colleagues during the post-lesson discussion caused them to rethink the approaches, activities and worksheets they used. Most importantly, the questions allowed them to consider the lesson and whether all that was planned and done really contributed to achieving the goals of the lesson.

Through practice made possible by all the teachers volunteering to teach the lesson, they became more proficient at observing lessons and collecting data on student thinking. Additionally, two teachers commented that due to their experience with lesson study they more carefully choose problems for both discussion and practice, look closely at the wording in selected problems to eliminate any ambiguity, and will better plan the sequence of problems on any future worksheets.

During the planning phase of the lesson study cycle, there was no detailed discussion of the scope and sequence (what students had learned in previous grades), accompanied by examination of the elementary textbooks and curriculum guide. However, it did highlight the teachers' previous strict adherence to the textbook, which in turn precipitated a subsequent review of the scope and sequence of the district's mathematics curriculum and the recognition of the need to align it with NCTM's Focal Points (NCTM, 2006). They recognized the need to use the "book more as a tool to help achieve the goal of the lesson and not to let the book become the goal." They also realized it was necessary to consider what students might have learned in previous years, how the concepts were taught, and what language was used in order to build upon students' prior knowledge and to understand the root of students' confusion.

Another realization was the need to move away from telling students too much to giving students an opportunity to come up with their own solution methods. To quote one teacher, "For true learning by the students, they need to be able to make or to see connections between what they already know and what it is we are trying to teach them." One teacher identified the lesson study process as an assessment tool that helps teachers see what students know about a topic and what knowledge they lack (misunderstanding). 


\section{Conclusions}

Observers in classrooms often hear teachers ask students to "think." Sometimes it is not clear about what and how students should be thinking. The APEC lesson study project, recognizing the intricacies in developing mathematical thinking, has devoted a series of conferences to the discussion of this very important topic. Observations of Japanese classrooms reveal the deliberate and explicit ways by which teachers help students learn and develop mathematical thinking skills; no steps are skipped, and no assumptions are made about student understanding.

Developing students' mathematical thinking requires a coordinated group effort, as exemplified by the lesson study process. Teachers learn from colleagues' data collected from observation of their students. The purpose of lesson study, however, is to inform daily instruction, when teachers are alone in the class with their students. By providing teachers with the opportunity to teach in front of colleagues and to collect data on student learning, thinking, and misunderstanding in colleagues' classrooms, lesson study focuses teachers' attention on how students interpret or misinterpret the lesson. Better understanding of students' thinking can help teachers develop lessons that build students' understanding rather than cause or contribute to their confusion.

Many teachers' goal is to develop lessons that flow smoothly. However, a lesson that unfolds exactly as orchestrated may not shed light on real student thinking and understanding. The students in this lesson study cycle revealed to us a great deal about their misunderstandings and tenuous grasp of concepts, providing us with crucial information on the necessary next steps to correct their misunderstanding and to provide the scaffolding needed to build their understanding. 


\section{References}

Fernandez, C. \& Yoshida, M. (2004) Lesson study: A Japanese approach to improving mathematics teaching and learning. Mahwah, NJ: Lawrence Erlbaum Associates.

Gould, P. (March, 2007). Developing mathematical reasoning through argumentation. In Progress report of the APECT project: Collaborative studies on innovations for teaching and learning mathematics in different cultures (II) - Lesson study focusing on mathematical thinking, CRICED and University of Tsukuba, pp. 163-168.

Henderson, P.B. et al. (December 2001) (ITiCSE 2001 working group). Striving for mathematical thinking. SIGCSE Inroads Vol. 33 , No 4, pp. 114-124 (Available at: http://blue.butler.edu/ phenders/striving.doc)

Hiebert, J., Gallimore, R., Garnier, H., Givvin, K. B., Hollingsworth, H., Jacobs, J., Chui, A. M., Wearne, D., Smith, M., Kersting, N., Manaster, A., Tseng, E., Etterbeek, W., Manaster, C., Gonzales, P., \& Stigler, J. (2003). Teaching Mathematics in Seven Countries: Results from the TIMSS 1999 Video Study, NCES (2003-013), U.S. Department of Education. Washington, DC: National Center for Education Statistics.

Katagiri, S. (March, 2007). Mathematical thinking and how to teach it. In Progress report of the APECT project: Collaborative studies on innovations for teaching and learning mathematics in different cultures (II) - Lesson study focusing on mathematical thinking, CRICED and University of Tsukuba, pp.105-157.

Lin, F.-L. (March, 2007). Designing mathematics conjecturing activities to foster thinking and constructing actively. in Progress report of the APECT project:

Collaborative studies on innovations for teaching and learning mathematics in different cultures (II) - Lesson study focusing on mathematical thinking, CRICED and University of Tsukuba, pp. 65-74.

Mullis, I.V.S., Martin, M.O., Gonzalez, E.J., Chrostowski, S.J. (2004). TIMSS 2003 international mathematics report: Findings from IEA's Trends in international mathematics and science study at the fourth and eighth grades. Chestnut Hill, MA: TIMSS \& PIRLS International Study Center, Lynch School of Education, Boston College, p. 251.

National Council of Teachers of Mathematics (2000). Principles and standards for school mathematics. Reston, VA: National Council of Teachers of Mathematics (www.nctm.org).

National Council of Teachers of Mathematics (2006). Focal Points. Reston, VA: National Council of Teachers of Mathematics (www.nctm.org/focalpoints). 
Schmidt, W., Houang, R. \& Cogan, L. (2002) A coherent curriculum: The case of mathematics, American Educator, summer, 2002 (Available at:

www.aft.org/pubs-reports/american_educator/summer2002/curriculum.pdf).

Stacey, K. (March, 2007). What is mathematical thinking and why is it important? in Progress report of the APECT project: Collaborative studies on innovations for teaching and learning mathematics in different cultures (II) - Lesson study focusing on mathematical thinking, CRICED and University of Tsukuba, pp. 39-48.

Takahashi, A., Watanabe, T., Yoshida, M. (2005). Improving content and pedagogical knowledge through kyozaikenkyu. In Wang-Iverson, P. \& Yoshida, M., Eds. Building our understanding of lesson study. Philadelphia: Research for Better Schools, pp. 101-110.

Tall, D. (March, 2007). Encouraging mathematical thinking that has both power and simplicity. in Progress report of the APECT project: Collaborative studies on innovations for teaching and learning mathematics in different cultures (II) - Lesson study focusing on mathematical thinking, CRICED and University of Tsukuba, pp. 49-64. 
Appendix 1: Ideal Students vs. Real Students

\section{Ideal Students}

* are prompt, polite, and prepared

* are respectful of each other and teacher

* persevere

* are motivated, interested, engaged

* are self-starters

* are self-reflective; engage in meta-cognition

* are active members of classroom discussions

* are responsible for their own learning

* take pride in their work

* are honest, have integrity

\section{Real Students}

* are unprepared: no tools, homework, mentally

* lack perseverance

* are unable/unwilling to think through problems

* are impulsive; act without thinking

* have a "tell me how to do it" attitude; just want to get it done

* don't take time to assess reasonableness of answer

* exhibit varying levels of interest and perseverance within each classroom

* display lack of understanding

* have no concern for quality work

* are bored?

* are too motivated by grades

* don't show thinking in writing (due to laziness?)

Were these lists written by the teachers in an effort to vent? Do they have real steps for turning their real students into ideal students? 
Appendix 2:

\section{Lesson Study at William Annin Middle School}

\section{Lesson study team members: Patricia Gambino, Tara Gialanella, Chad Griffiths, Mary Henry, Marian Palumbo, Elizabeth Slack}

\section{Title of lesson: Assessing Student Understanding of Percent Concepts}

2. Lesson Goals: Students in grade 7 Algebra I from William Annin Middle School will:

a. Understand the value for using efficient methods when solving percent problems

b. Compare and contrast the relationship(s) between determining the "part" and "determining the "whole" in a percent problem

Class organization: Students will work with a partner to solve the problem. One student from selected pairs will put the solution on the board.

\section{Rationale}

Initially, as we worked with our seventh-grade students, we all became aware that our students did not have a deep understanding of the concept of percent. Moreover, it was clear that many students did not see the connection between fractions, decimals, percents, and proportions. Therefore, we decided to reexamine this concept. We felt that we needed to assess our students' current grasp of the topic of percent and uncover the sources of their misunderstandings and why they are not making the connections. It was at this point that it became clear that this topic, not the one we had originally chosen, should be the focus of our lesson study. Therefore, we decided that we would present our students with three problems involving percents and sale prices. Our students would have to decide at which store to buy an iPod in order to pay the lowest price. We chose this scenario, because we thought that it would grab our students' interests and be familiar to them. In addition, knowledge about and facility with percents is an important life-long skill.

Initially we presented the lesson to our regular seventh-grade mathematics students, some of whom did not find the lesson particularly challenging, as they were applying the same rote procedures they had learned in earlier 
grades. When we revised the lesson for the seventh-grade students enrolled in Algebra I, we realized we needed to give them additional opportunities to compare and contrast the various types of percent problems and to focus their attention on using efficient methods for solving the problems.

Scope and Sequence for Fractions, Decimals, Percents

\begin{tabular}{|c|c|c|c|c|}
\hline Grade 2 & Grade 3 & Grade 4 & Grade 5 & Grade 6 \\
\hline $\begin{array}{l}\text { Fraction } \\
\text { equivalences } \\
\text { (informal } \\
\text { exploration) }\end{array}$ & $\begin{array}{l}\text { Fraction } \\
\text { equivalenc } \\
\text { es } \\
\text { continued } \\
\text { - Decimal } \\
\text { concept } \\
\text { introduced }\end{array}$ & $\begin{array}{l}\text { - Operations with } \\
\text { fractions/decimals } \\
\text { introduced } \\
\text { - } \text { Comparing, } \\
\text { ordering decimals } \\
\text { - } \text { Adding/subtracting } \\
\text { decimals } \\
\text { - Fraction concepts } \\
\text { - Adding/subtracting } \\
\text { fractions } \\
\text { - Percents } \\
\text { introduced } \\
\text { - Convert fractions } \\
\text { to decimals and } \\
\text { percents w/ } \\
\text { calculator } \\
\text { - Multiply/divide } \\
\text { decimals }\end{array}$ & $\begin{array}{l}\text { - Add, subtract } \\
\text { fractions } \\
\text { - Multiply } \\
\text { fractions } \\
\text { using area } \\
\text { model } \\
\text { - Relate } \\
\text { fractions, } \\
\text { decimals, } \\
\text { percents } \\
\text { - Convert } \\
\text { fractions to } \\
\text { decimals, } \\
\text { percents } \\
\text { - Find percent } \\
\text { of a number } \\
\text { - Use unit } \\
\text { fractions to } \\
\text { find the } \\
\text { whole } \\
\text { - Use percents } \\
\text { to } \\
\text { interpret/crea } \\
\text { te circle } \\
\text { graphs }\end{array}$ & $\begin{array}{l}\text { - Convert } \\
\text { between } \\
\text { fraction, } \\
\text { decimal, } \\
\text { percent } \\
\text { - Review } \\
\text { finding } \\
\text { percent of a } \\
\text { number } \\
\text { - Use } \\
\text { proportions } \\
\text { to solve } \\
\text { percent } \\
\text { problems } \\
\text { - Application: } \\
\text { calculate tip, } \\
\text { discounts, } \\
\text { and sales tax }\end{array}$ \\
\hline
\end{tabular}


The Problem: The Carters are buying a new iPod Nano. Three stores have on sale this week the model they want, but they have decided to shop at Ralph's because they think Ralph's is offering a "double discount." Here are the ads. Did the Carters make a wise decision? Explain.

\begin{tabular}{|l|l|l|}
\hline $\begin{array}{l}\text { Radio Shop } \\
\text { Original Price \$172 } \\
\text { Discount: } 1 / 4 \text { off }\end{array}$ & $\begin{array}{l}\text { Discount City } \\
\text { Original Price: } \$ 180 \\
\text { Discount: } 30 \% \text { off }\end{array}$ & $\begin{array}{l}\text { Ralph's } \\
\text { Original Price } \$ 180 \\
\text { Discount: } 10 \% \text { off with an } \\
\text { additional } 20 \% \text { off the } \\
\text { discounted price }\end{array}$ \\
\hline
\end{tabular}

The management at Ralph's decided to change their ad to attract more customers. Here is the new ad:

Original Price $\$ 180$. Discount $20 \%$ off with an additional $10 \%$ off the discounted price. How does this change the sale price? Explain.

\section{Lesson Plan}

\begin{tabular}{|c|c|c|c|}
\hline Time & Teacher Activity & $\begin{array}{l}\text { Anticipated Student } \\
\text { Thinking and Activity }\end{array}$ & $\begin{array}{l}\text { Point To Notice } \\
\text { and Evaluate }\end{array}$ \\
\hline $\begin{array}{l}0-3 \\
\text { min }\end{array}$ & $\begin{array}{l}\text { Set up the problem and check } \\
\text { for student understanding } \\
\text { - Teacher discusses each } \\
\text { store one at a time, } \\
\text { displaying props } \\
\text { - Clarify any student } \\
\text { misunderstanding or } \\
\text { questions }\end{array}$ & & \\
\hline $\begin{array}{l}3-8 \\
\text { min. }\end{array}$ & $\begin{array}{l}\text { Tell students they should work } \\
\text { on the problem with their } \\
\text { partner. Both students are } \\
\text { responsible for showing the } \\
\text { solution strategies on their } \\
\text { individual sheets of paper. } \\
\text { When both students are } \\
\text { finished they can begin work } \\
\text { on the additional problem } \\
\text { (different colored sheet of } \\
\text { paper). } \\
\text { - Teacher circulates to } \\
\text { identify various } \\
\text { solution methods for } \\
\text { Ralph's only and }\end{array}$ & $\begin{array}{l}\text { Ralph's } \\
.1(180)=18,180- \\
18=162 \\
162(.2)=32.4,162- \\
32.4=129.60 \\
\text { order unimportant? } \\
.9 * .8 * 180=129.60 \\
.72(180)=129.60\end{array}$ & $\begin{array}{l}\text { What distribution of } \\
\text { students used } \\
\text { different methods? }\end{array}$ \\
\hline
\end{tabular}




\begin{tabular}{|c|c|c|c|}
\hline Time & Teacher Activity & $\begin{array}{l}\text { Anticipated Student } \\
\text { Thinking and Activity }\end{array}$ & $\begin{array}{l}\text { Point To Notice } \\
\text { and Evaluate }\end{array}$ \\
\hline & $\begin{array}{l}\text { selects students to } \\
\text { record work on board. } \\
\text { While circulating, } \\
\text { distribute second set of } \\
\text { problems to be } \\
\text { completed when } \\
\text { students finish initial } \\
\text { problem, (distribution } \\
\text { method is optional) }\end{array}$ & & \\
\hline $\begin{array}{l}8-11 \\
\min \end{array}$ & $\begin{array}{l}\text { Poll students by show of hands } \\
\text { How many think the Carters } \\
\text { made a wise decision choosing } \\
\text { Ralph's? How many think the } \\
\text { Carters made a poor decision? } \\
\text { Why might the Carters think } \\
\text { that Ralph's would have the } \\
\text { lower sale price? } \\
\text { - Facilitate a class } \\
\text { discussion }\end{array}$ & $\begin{array}{l}\text { The ad is misleading } \\
\text { The words say a } 10 \% \\
\text { discount followed by a } \\
20 \% \text { discount, which } \\
\text { means that first you } \\
\text { have to multiply by } \\
10 \% \text {, find the sale price } \\
\text { and then find the } 20 \% \\
\text { discount from the sale } \\
\text { price. } \\
\text { A } 10 \% \text { discount } \\
\text { followed by a } 20 \% \\
\text { discount is not the same } \\
\text { as a } 30 \% \text { discount - } \\
\text { that is what the Carters } \\
\text { were thinking. }\end{array}$ & $\begin{array}{l}\text { What comments do } \\
\text { students make about } \\
\text { the Carters } \\
\text { decision? } \\
\text { What distribution of } \\
\text { students thought the } \\
\text { Carters made a wise } \\
\text { decision? } \\
\text { What distribution of } \\
\text { students thought the } \\
\text { Carters made a poor } \\
\text { decision? }\end{array}$ \\
\hline $\begin{array}{l}11-20 \\
\min \end{array}$ & $\begin{array}{l}\text { Students present their } \\
\text { solutions for Ralph's } \\
\text { - Teacher calls attention } \\
\text { and facilitates a short } \\
\text { discussion about the } \\
\text { more "efficient } \\
\text { solutions" } \\
\text { - If necessary introduce } \\
\text { solution } \\
.9(.8)(180) \text { and } .72(180)\end{array}$ & $\begin{array}{l}.1(180)=18,180- \\
18=162 \\
162(.2)=32.4,162- \\
32.4=129.60 \\
.9 * .8 * 180=129.60 \\
.72(180)=129.60\end{array}$ & $\begin{array}{l}\text { What distribution of } \\
\text { students used } \\
\text { efficient methods? } \\
\text { What distribution of } \\
\text { students }\end{array}$ \\
\hline $\begin{array}{l}20-22 \\
\text { min. }\end{array}$ & $\begin{array}{l}\text { Introduce the new ad - (show) } \\
\text { The management at Ralph's } \\
\text { decided to change their ad to } \\
\text { attract more customers. Here is }\end{array}$ & $\begin{array}{l}\text { It doesn't change } \\
\text { Multiplication is } \\
\text { commutative } \\
.9(.8)(180)=\end{array}$ & $\begin{array}{l}\text { What distribution of } \\
\text { students } \\
\text { demonstrates } \\
\text { application of the }\end{array}$ \\
\hline
\end{tabular}




\begin{tabular}{|c|c|c|c|}
\hline Time & Teacher Activity & $\begin{array}{l}\text { Anticipated Student } \\
\text { Thinking and Activity }\end{array}$ & $\begin{array}{l}\text { Point To Notice } \\
\text { and Evaluate }\end{array}$ \\
\hline & $\begin{array}{l}\text { the new ad: } \\
\text { Original Price } \$ 180 \text {, Discount } \\
20 \% \text { off with an additional } \\
10 \% \text { off the discounted price. } \\
\text { How does this change the sale } \\
\text { price? Explain } \\
\text { - Facilitate a short } \\
\quad \text { discussion }\end{array}$ & $.8(.9)(180)$ & $\begin{array}{l}\text { commutative } \\
\text { property to this } \\
\text { example? }\end{array}$ \\
\hline $\begin{array}{l}22-30 \\
\min .\end{array}$ & $\begin{array}{l}\text { Call the students' attention to } \\
\text { the additional problem and } \\
\text { have them continue to work on } \\
\text { that one (computer problem): } \\
\text { A computer is discounted } \\
20 \% \text { from its original price } \\
\text { because it didn't sell. The } \\
\text { store took an additional } \\
30 \% \text { off the discounted } \\
\text { price. Barbara purchased } \\
\text { the computer for } \$ 896 . \\
\text { What was the original } \\
\text { price of the computer? } \\
\text { Teacher circulates to } \\
\text { collect solutions }\end{array}$ & $\begin{array}{l}896 / .7 / .8=1600 \\
896 / .56=1600\end{array}$ & $\begin{array}{l}\text { What distribution of } \\
\text { students used an } \\
\text { efficient method? } \\
\text { What distribution of } \\
\text { students was able to } \\
\text { transfer their } \\
\text { knowledge of the } \\
\text { first problem to this } \\
\text { problem? }\end{array}$ \\
\hline $\begin{array}{l}30-36 \\
\min \end{array}$ & $\begin{array}{l}\text { Teacher facilitates a discussion } \\
\text { about the various solution } \\
\text { methods and then summarizes } \\
\text { by comparing and contrasting } \\
\text { both problems, and } \\
\text { generalizing } \\
.9(.8)(180)=\mathrm{x} \\
.9(.8)(\text { whole })=\text { part } \\
.8(.7)(\mathrm{x})=896 \\
.8(.7)(\text { whole })=\text { part }\end{array}$ & & \\
\hline $\begin{array}{l}36-40 \\
\min \end{array}$ & $\begin{array}{l}\text { Teacher closes the lesson, } \\
\text { asking the students to reflect } \\
\text { on their learning and then } \\
\text { complete the questions on the } \\
\text { reflection sheet, }\end{array}$ & & \\
\hline
\end{tabular}


Name

Date

The Problem: The Carters are buying a new iPod Nano. Three stores have on sale this week the model they want, but they have decided to shop at Ralph's because they think Ralph's is offering a "double discount." Here are the ads. Did the Carters make a wise decision? Explain.

\begin{tabular}{|l|l|l|}
\hline $\begin{array}{l}\text { Radio Shop } \\
\text { Original Price } \$ 172 \\
\text { Discount: } 1 / 4 \text { off }\end{array}$ & $\begin{array}{l}\text { Discount City } \\
\text { Original Price: } \$ 180 \\
\text { Discount: } 30 \% \text { off }\end{array}$ & $\begin{array}{l}\text { Ralph's } \\
\text { Original Price } \$ 180 \\
\text { Discount: } 10 \% \text { off with an } \\
\text { additional 20\% off the } \\
\text { discounted price }\end{array}$ \\
\hline & & \\
& & \\
& \\
\end{tabular}


Name:

Date:

\section{Try This One!!!}

1. A computer is discounted $20 \%$ from its original price because it didn't sell. The store took an additional $30 \%$ off the discounted price. Barbara purchased the computer for $\$ 896$. What was the original price of the computer? 
Name

Date

What mathematics did you learn or think about today?

In what ways was the lesson challenging?

In what ways was the lesson interesting? 
Appendix 3: Template for data collection

Collection of Student Thinking

\begin{tabular}{|c|c|c|c|}
\hline & $\begin{array}{l}\text { Radio Shop } \\
\text { Original Price } \$ 172 \\
\text { Discount: } 1 / 4 \text { off }\end{array}$ & $\begin{array}{l}\text { Discount City } \\
\text { Original Price: } \\
\$ 180 \\
\text { Discount: } 30 \% \text { off }\end{array}$ & $\begin{array}{l}\text { Ralph's } \\
\text { Original Price } \$ 180 \\
\text { Discount: } 10 \% \text { off } \\
\text { with an additional } \\
20 \% \text { off the } \\
\text { discounted price }\end{array}$ \\
\hline $\begin{array}{l}\text { Use multiplication } \\
\text { with decimal to find } \\
\text { the discount and } \\
\text { then subtract }\end{array}$ & & & \\
\hline $\begin{array}{l}\text { Use multiplication } \\
\text { with fraction to find } \\
\text { the discount and } \\
\text { then subtract }\end{array}$ & & & \\
\hline $\begin{array}{l}\text { Use multiplication } \\
\text { with } \\
(100-x) \%\end{array}$ & & & \\
\hline $\begin{array}{l}\text { Use multiplication } \\
\text { with (whole-part) as } \\
\text { a fraction }\end{array}$ & & & \\
\hline $\begin{array}{l}\text { Use a proportion to } \\
\text { solve the problem } \\
\text { with } x / 100\end{array}$ & & & \\
\hline $\begin{array}{l}\text { Use a proportion to } \\
\text { solve the problem } \\
\text { with }(100-x) / 100\end{array}$ & & & \\
\hline $\begin{array}{l}\text { Non-solutions for } \\
\text { Ralph's - addition of } \\
\text { percents }\end{array}$ & & & \\
\hline $\begin{array}{l}\text { Other solutions } \\
\text { (note solution) }\end{array}$ & & & \\
\hline
\end{tabular}


Appendix 4: Assessing teacher learning during lesson study

1. Reflect on 1-3 things you learned from the lesson study experience.

2. What did you do prior to lesson study that hampered student learning?

3. What changes might you make to enhance student learning?

4. In what ways have you deepened your own understanding of mathematics?

5. What did you learn from observing colleagues' classrooms?

6. What did you learn from your colleagues' observation of your students?

7. What has changed since the lesson study cycle? 